\title{
Growth and tolerance of healthy, term infants fed lower protein extensively hydrolyzed or amino acid-based formula: double-blind, randomized, controlled trial
}

Craig B. Adams', William H. Johnston ${ }^{2}$, Harold Deulofeut ${ }^{3}$, Joseph Leader ${ }^{4}$, Robbie Rhodes ${ }^{5}$, Michael Yeiser ${ }^{6}$, Cheryl L. Harris ${ }^{7}$, Jennifer L. Wampler ${ }^{7^{*}} \mathbb{D}$, Rebecca J. Hill ${ }^{7}$ and Timothy Cooper ${ }^{7}$

\begin{abstract}
Background: Optimal protein level in hypoallergenic infant formulas is an area of ongoing investigation. The aim was to evaluate growth of healthy term infants who received extensively hydrolyzed (EH) or amino acid (AA)-based formulas with reduced protein.

Methods: In this prospective, multi-center, double-blind, controlled, parallel group study, infants were randomized to receive a marketed EH casein infant formula at $2.8 \mathrm{~g}$ protein/100 kcal (Control) or one of two investigational formulas: EH casein formula at $2.4 \mathrm{~g}$ protein/100 kcal (EHF) or AA-based formula at $2.4 \mathrm{~g}$ total protein equivalents/ $100 \mathrm{kcal}$ (AAF). Control and EHF each had $2 \times 10^{7}$ CFU Lactobacillus rhamnosus GG/100 kcal. Anthropometrics were measured and recall of formula intake, tolerance, and stool characteristics was collected at 14, 30,60, 90, 120 days of age. Primary outcome was weight growth rate (g/day) between 14 and 120 days of age (analyzed by ANOVA). Medically confirmed adverse events were recorded throughout the study.

Results: No group differences in weight or length growth rate from 14 to 120 days were detected. With the exception of significant differences at several study time points for males, no group differences were detected in mean head circumference growth rates. However, mean achieved weight, length, and head circumference demonstrated normal growth throughout the study period. No group differences in achieved weight or length (males and females) and head circumference (females) were detected and means were within the WHO growth 25th and 75th percentiles from 14 to 120 days of age. With the exception of Day 90, there were no statistically significant group differences in achieved head circumference for males; means remained between the WHO 50th and 75th percentiles for growth at Days 14, 30, and 60 and continued along the 75th percentile through Day 120. No differences in study discontinuation due to formula were detected. The number of participants for whom at least one adverse event was reported was similar among groups.
\end{abstract}

(Continued on next page)

* Correspondence: jennifer.wampler@rb.com

${ }^{7}$ Medical Affairs and Scientific Affairs, Reckitt/Mead Johnson Nutrition Institute, Evansville, IN 47721, USA

Full list of author information is available at the end of the article

C C The Author(s). 2021 Open Access This article is licensed under a Creative Commons Attribution 4.0 International License, which permits use, sharing, adaptation, distribution and reproduction in any medium or format, as long as you give appropriate credit to the original author(s) and the source, provide a link to the Creative Commons licence, and indicate if changes were made. The images or other third party material in this article are included in the article's Creative Commons licence, unless indicated otherwise in a credit line to the material. If material is not included in the article's Creative Commons licence and your intended use is not permitted by statutory regulation or exceeds the permitted use, you will need to obtain permission directly from the copyright holder. To view a copy of this licence, visit http://creativecommons.org/licenses/by/4.0/ The Creative Commons Public Domain Dedication waiver (http://creativecommons.org/publicdomain/zero/1.0/) applies to the data made available in this article, unless otherwise stated in a credit line to the data. 
(Continued from previous page)

Conclusions: This study demonstrated hypoallergenic infant formulas at $2.4 \mathrm{~g}$ protein/100 kcal were safe, well-

tolerated, and associated with appropriate growth in healthy term infants from 14 to 120 days of age.

Trial registration: ClinicalTrials.gov, ClinicalTrials.gov Identifier: NCT01354366. Registered 13 May 2011.

Keywords: Infant formula, Extensively hydrolyzed protein, Amino acid, Lactobacillus rhamnosus GG

\section{Background}

Cow's milk allergy (CMA) is one of the most common allergies in infancy, with a clinically diagnosed prevalence estimated up to $3 \%$ (as reviewed [1-5]). Hypoallergenic formulas, including extensively hydrolyzed (EH) protein formulas or amino acid-based (AA) formulas, are recommended for the dietary management of infants with CMA who cannot be breastfed. Typically, the majority of infants with CMA are managed effectively on an $\mathrm{EH}$ formula, however, approximately $10 \%$ of infants who exhibit severe CMA and/or multiple food allergies will require dietary management utilizing an AA-based formula [6].

Increasing evidence supports lowering total protein content in both hypoallergenic formulas and routine infant formulas to be more in line with the amount of protein found in human milk. Human milk is dynamic in composition and declines in protein content as lactation progresses [7] whereas infant formula composition is static for each age stage and formulated with higher protein concentrations than human milk to meet essential AA requirements $[8,9]$. Targeting a lower protein concentration in infant formulas, more similar to that of human milk in order to support growth in line with breastfed trajectories, has increasing support [9-11]. As a result, some regulatory recommendations have been updated for infant formula protein composition by lowering the maximum target value. For example, the European Union has recently lowered its maximum recommended value for protein hydrolysates in infant formula from $3 \mathrm{~g} / 100 \mathrm{kcal}$ [12] to $2.8 \mathrm{~g} / 100 \mathrm{kcal}$ [13].

Though management of CMA is the primary goal of $\mathrm{EH}$ or AA formula usage, a reduction of protein in infant formula requires consideration with respect to growth and tolerance. The overall importance of adequate protein for infant growth and development is well understood. Both an EH and an AA-based formula that had protein at $2.8 \mathrm{~g} / 100 \mathrm{kcal}$ have been demonstrated to adequately support typical growth and safety [14]. In the current study we aimed to examine the growth and tolerance of healthy, term infants fed an EH or AA formula that have reduced protein/protein equivalent at $2.4 \mathrm{~g} /$ $100 \mathrm{kcal}$. Rate of weight gain (g/day) from 14 to 120 days of age was evaluated as the primary variable to establish that protein at this concentration is well-accepted, tolerated and provides adequate growth.

\section{Methods}

\section{Study design}

Good Manufacturing Practice guidelines are provided by the US Food and Drug Administration to insure that an infant formula meets the quality factor of normal physical growth $[15,16]$. Consequently, the current multicenter, double-blind, randomized, controlled, parallel-group, prospective trial is similar in design to previously reported studies $[17,18]$ in order to report consistent growth outcomes across different study cohorts. The research protocol and informed consent forms observing the Declaration of Helsinki (including October 1996 amendment) were approved by: the University of Louisville Institutional Review Board (IRB; Louisville, KY); the University of Nebraska Medical Center IRB (Omaha, $\mathrm{NE}$ ); Western IRB (Olympia, WA); and Schulman IRB (now known as Advarra, Columbia, MD). The study complied with good clinical practices. Mothers who had decided to exclusively provide infant formula were screened for study eligibility. Parents or legally authorized representatives provided written informed consent prior to enrollment.

Healthy 12- to 16-day old infants were recruited at 27 clinical sites in the United States. Eligible infants were singleton births at 37-42 weeks' gestational age with birth weight $\geq 2500 \mathrm{~g}$ and solely receiving infant formula at least $24 \mathrm{~h}$ prior to randomization. Exclusion criteria included history of underlying disease or congenital malformation likely to interfere with normal growth and development or participant evaluation; feeding difficulties or history of formula intolerance; weight at randomization $<98 \%$ of birth weight; large for gestational age from mother who was diabetic at childbirth; and immunodeficiency.

A computer-generated, randomization schedule stratified by sex was created by the study sponsor and provided in sealed consecutively numbered envelopes for each study site. At each study site the next sequential envelope was opened from the appropriate set to assign study formula. Two unique codes (known only to the sponsor) were used to designate each study formula. Study formulas were dispensed to parents at each study visit prior to completion or withdrawal. Product labels and the sealed envelopes did not allow direct unblinding by the study site. Study monitoring personnel were also blinded to study product identification. In the event of a 
medical emergency (in which knowledge of the study formula was critical to the participant's management) blinding for a participant could be broken by study sponsor personnel. In this study, it was not necessary to break the study code prematurely.

Participants were enrolled between July 2011 and August 2012 and were randomly assigned to receive one of three study formulas (Mead Johnson Nutrition, Evansville, IN) from 14 to 120 days of age: 1) an EH casein infant formula at $2.8 \mathrm{~g}$ protein $/ 100 \mathrm{kcal}$ (Control; marketed Nutramigen $^{\mathrm{Tw}}$ with Enflora ${ }^{\mathrm{TM}}$ LGG $^{\circ}$ ); 2) an investigational $\mathrm{EH}$ casein formula at $2.4 \mathrm{~g}$ protein/100 kcal (EHF); or 3) an investigational AA-based formula at $2.4 \mathrm{~g}$ total protein equivalents $/ 100 \mathrm{kcal}$ (AAF). Control and EHF each had $2 \times 10^{7} \mathrm{CFU}$ Lactobacillus rhamnosus GG (LGG)/ $100 \mathrm{kcal}$ (Table 1).

\section{Study objectives and outcomes}

Evaluation of growth and tolerance in healthy, term infants was the study objective. Body weight, length, and head circumference (anthropometric measures) were recorded at study visits corresponding to 14 (12-16 days; enrollment), $30( \pm 3), 60( \pm 3), 90( \pm 3), 120( \pm 4)$ days of age.

At all study visits parents completed a 24-h recall of tolerance (fussiness and gassiness) and stool characteristics (frequency and consistency); study formula intake (fluid oz./day) was reported beginning at the 30 days of age visit. We have previously characterized tolerance using the same reporting scales $[17,18,19,20,21] \mathrm{Al}-$ though parental recall may vary among individuals, participant randomization ensures balance between study groups. Responses were scaled for amount of gas (none $=0$, slight amount $=1$, moderate amount $=2$, excessive amount $=3$ ); fussiness (not fussy $=0$, slightly fussy $=1$, moderately fussy $=2$, very fussy $=3$, extremely fussy $=4$ ); and stool consistency (hard $=1$, formed $=2$, soft $=3$, unformed or seedy, watery $=4$ ). Each participant's parent or caregiver was provided with pictures to guide in stool consistency rating. Adverse events were coded according to specific event and the body system involved.

\section{Statistical methods}

Weight growth rate from 14 to 120 days of age was the primary outcome. Detection of a clinically relevant difference of $3 \mathrm{~g} /$ day in weight gain from 14 to 120 days of age $(80 \%$ power) was used to determine the sample size. Enrollment of approximately 91 males and 66 females was needed in each group with expected completion of 59 male and 43 female participants per study group (assuming a standard deviation of $6.5 \mathrm{~g} /$ day for male and $5.5 \mathrm{~g} /$ day for female participants). Linear regression of weight on age was calculated for each participant and
Table 1 Nutrient composition per $100 \mathrm{kcal}$

\begin{tabular}{|c|c|c|c|}
\hline \multirow[t]{2}{*}{ Nutrient } & \multicolumn{3}{|c|}{ Study Formula, target values } \\
\hline & Control $^{\mathrm{a}}$ & $\mathrm{EHF}^{\mathrm{a}, \mathrm{b}}$ & AAF \\
\hline Total Protein, $g^{c}$ & 2.8 & 2.4 & - \\
\hline Protein Equivalent, $\mathrm{g}^{\mathrm{d}}$ & - & - & 2.4 \\
\hline Total Fat, $\mathrm{g}^{\mathrm{e}}$ & 5.3 & 5.3 & 5.3 \\
\hline Linoleic acid, mg & 860 & 860 & 860 \\
\hline a-Linolenic acid, mg & 80 & 80 & 80 \\
\hline ARA, mg & 34 & 34 & 34 \\
\hline DHA, mg & 17 & 17 & 17 \\
\hline Total Carbohydrate, $\mathrm{g}^{\mathrm{f}}$ & 10.3 & 10.7 & 10.7 \\
\hline Vitamin A, IU & 300 & 300 & 300 \\
\hline Vitamin D, IU & 50 & 50 & 50 \\
\hline Vitamin E, IU & 2 & 2 & 2 \\
\hline Vitamin K, mcg & 9 & 9 & 8 \\
\hline Thiamin, mcg & 80 & 80 & 80 \\
\hline Riboflavin, mcg & 90 & 90 & 90 \\
\hline Vitamin B6, mcg & 60 & 60 & 60 \\
\hline Vitamin B12, mcg & 0.3 & 0.3 & 0.3 \\
\hline Niacin, mcg & 1000 & 1000 & 1000 \\
\hline Folic Acid, mcg & 16 & 16 & 16 \\
\hline Pantothenic Acid, mcg & 500 & 500 & 500 \\
\hline Biotin, mcg & 3 & 3 & 3 \\
\hline Vitamin C, mg & 12 & 12 & 12 \\
\hline Choline, mg & 24 & 24 & 24 \\
\hline Inositol, mg & 17 & 17 & 17 \\
\hline Calcium, mg & 94 & 94 & 94 \\
\hline Phosphorus, mg & 52 & 52 & 52 \\
\hline Magnesium, mg & 8 & 8 & 11 \\
\hline Iron, mg & 1.8 & 1.8 & 1.8 \\
\hline Zinc, mg & 1 & 1 & 1 \\
\hline Manganese, mcg & 25 & 25 & 60 \\
\hline Copper, mcg & 75 & 75 & 75 \\
\hline lodine, mcg & 15 & 15 & 15 \\
\hline Selenium, mcg & 2.8 & 2.8 & 2.8 \\
\hline Sodium, mg & 47 & 41 & 43 \\
\hline Potassium, mg & 110 & 104 & 110 \\
\hline Chloride, mg & 86 & 81 & 79 \\
\hline
\end{tabular}

a Lactobacillus rhamnosus GG

${ }^{b}$ Sources of protein: casein hydrolysate, L-cystine, L-tyrosine, L-tryptophan

c Exempt infant formula [16]

d $100 \%$ Free amino acids

e Sources of fat: Blend of palm olein, soy, coconut, and high oleic sunflower oils; single cell oils as a source of ARA and DHA

f Sources of carbohydrate for Control and EHF: corn syrup solids, modified corn starch and for AAF: corn syrup solids, modified tapioca starch

analysis of variance (ANOVA) was used to assess growth rates from 14 to $30,60,90$, or 120 days of age. A onetailed test, as outlined in guidance provided by the 
American Academy of Pediatrics (AAP) Task Force on Clinical Testing of Infant Formulas [22] was used to compare mean weight growth rates by sex for the investigational formula groups with the control.

Secondary outcomes included other anthropometric and tolerance measures and medically confirmed adverse events. Participant characteristics (race, ethnicity, sex, family history of allergy) and adverse events were analyzed by Fisher's exact test. Achieved weight, length, and head circumference; length and head circumference growth rates; formula intake; and stool frequency were analyzed by ANOVA with two exceptions. For females, because a difference in head circumference was detected at enrollment, analysis of covariance (ANCOVA) with covariate head circumference at enrollment was used to analyze head circumference growth rates and achieved head circumference. Stool consistency, fussiness, and gas were analyzed using the Cochran-Mantel-Haenszel $(\mathrm{CMH})$ row mean score test. With the exception of $p$ values reported from the analysis of weight gain based on one-tailed tests, all other $p$-values reported were based on two-tailed tests. When the overall comparison of the three groups was significant, unadjusted pairwise group comparisons were performed. All testing was conducted at $\alpha=0.05$. All analyses were conducted using SAS version 9.2 (Cary, NC).

\section{Results}

\section{Participants}

A total of 509 participants were enrolled and randomized (Control: 175; EHF: 173; AAF: 161). Participants who were randomized but consumed no study formula (Control: 2; EHF: 3; AAF: 2) were not included in subsequent analyses (Fig. 1). Anthropometric measures at birth, family history of allergy, and sex, race, and ethnic distribution were similar among groups (data not shown). With the exception of significantly lower mean $( \pm \mathrm{SE})$ head circumference for female infants in the Control versus the EHF group $(35.5 \pm 0.1$ vs $36.0 \pm 0.1 \mathrm{~cm}$; $P=0.004)$, no differences in body weight or length, or head circumference by sex were observed among groups at study enrollment (Table 2). No statistically significant group differences were detected for overall study discontinuation (Control: 56, 32\%; EHF: 64, 38\%; AAF: 49, $31 \%$ ) or discontinuation related to study formula (Control: 23, 13\%; EHF: 26, 15\%; AAF: 26, 16\%). In the total study population, $52(10 \%)$ participants (Control: 17; EHF: 18; AAF: 17) discontinued due to formula intolerance as determined by the study investigator; fussiness (Control: 10; EHF: 10; AAF: 7) was the most common indicator. Parental decision was the most common reason for discontinuation unrelated to study formula (67 participants, 13\%). A total of 333 infants completed the study (Control: 117; EHF: 106; AAF: 110).

\section{Growth}

Growth rates were analyzed from 14 to 120 days of age. No statistically significant group differences in the primary outcome, weight growth rate from Day 14 to 120 , were detected by sex (Table 3). No statistically significant group differences in weight or length growth rates were detected by sex for any age range. In addition, no significant group differences were observed for mean achieved weight or length at any measured time point. For all groups at all measured time points, mean achieved weights plotted within the 25th and 50th percentiles for male (Fig. 2a) and female (Fig. 2b) participants and mean achieved lengths plotted within the 50th

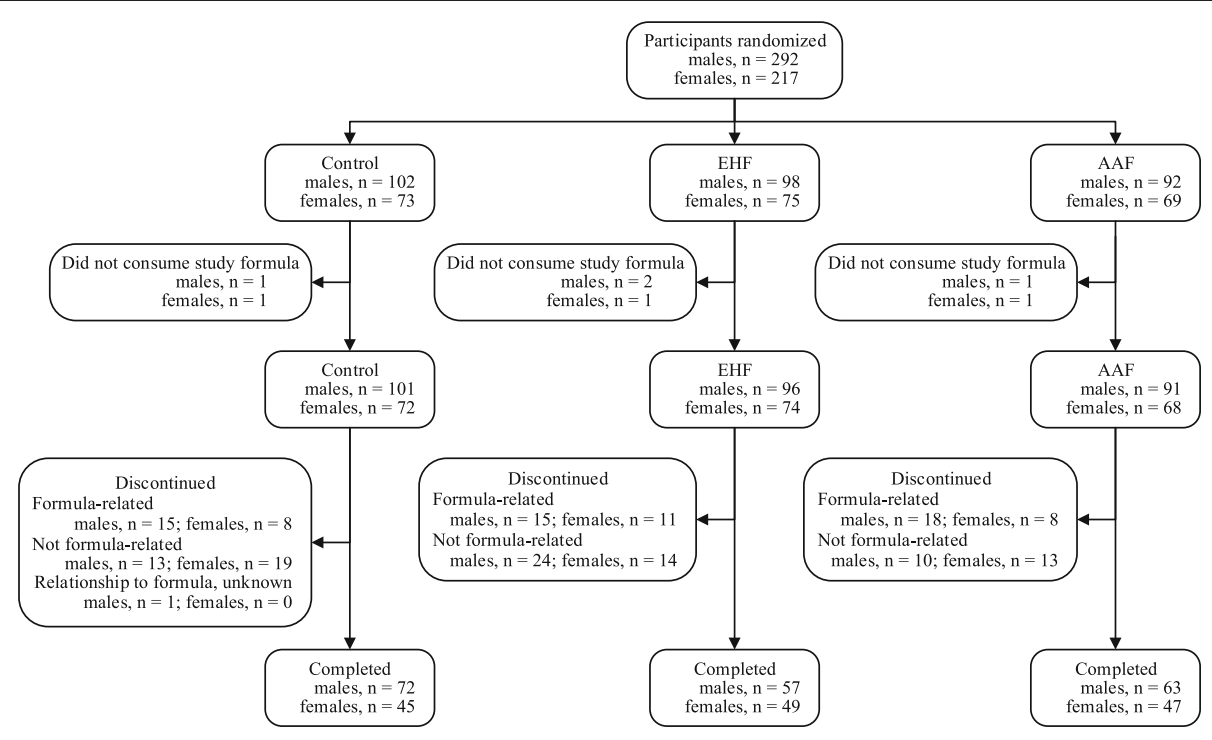

Fig. 1 Flow of study participants 
Table $\mathbf{2}$ Infant characteristics at study entry

\begin{tabular}{|c|c|c|c|c|}
\hline & \multicolumn{3}{|c|}{ Study Group } & \multirow{2}{*}{$\begin{array}{c}\text { Overal } \\
P\end{array}$} \\
\hline & Control & EHF & AAF & \\
\hline Total number of participants & 173 & 170 & 159 & 0.935 \\
\hline males/females, n & $101 / 72$ & $96 / 74$ & $91 / 68$ & \\
\hline \multicolumn{5}{|l|}{ males $^{\mathrm{a}}$} \\
\hline Weight (g) & $3730.9 \pm 44.3$ & $3689.8 \pm 45.4$ & $3684.7 \pm 46.6$ & 0.729 \\
\hline Length (cm) & $52.7 \pm 0.2$ & $52.5 \pm 0.2$ & $52.4 \pm 0.2$ & 0.638 \\
\hline Head circumference $(\mathrm{cm})$ & $36.4 \pm 0.1$ & $36.1 \pm 0.1$ & $36.2 \pm 0.1$ & 0.304 \\
\hline \multicolumn{5}{|l|}{ females $^{a}$} \\
\hline Weight (g) & $3482.7 \pm 45.8$ & $3626.7 \pm 45.2$ & $3554.1 \pm 47.1$ & 0.084 \\
\hline Length $(\mathrm{cm})$ & $51.5 \pm 0.2$ & $52.0 \pm 0.2$ & $51.5 \pm 0.2$ & 0.176 \\
\hline Head circumference (cm) & $35.5 \pm 0.1 \dagger$ & $36.0 \pm 0.1$ & $35.6 \pm 0.1$ & $0.013+$ \\
\hline
\end{tabular}

${ }^{a}$ Mean \pm standard error (SE)

†Significantly different, Control vs EHF $(P=0.004)$

and 75th percentiles for male (Fig. 3a) and female (Fig. $3 \mathrm{~b})$ participants using the WHO growth charts [23, 24]. For head circumference growth rate, significant group differences were detected for males including: higher growth rate in the EHF or AAF versus the Control group from Day 14 to 30; higher for AAF versus Control from Day 14 to 60; higher for AAF versus Control or EHF from Day 14 to 90; and higher for AAF versus the Control or EHF from Day 14 to 120 (Table 3). In addition for males, mean $( \pm S E)$ achieved head circumference $(\mathrm{cm})$ was significantly higher at Day 90 for AAF $(41.5 \pm 0.2)$ versus Control $(41.0 \pm 0.2 ; P=0.033)$ or EHF $(40.9 \pm 0.2 ; P=0.029)$; however, the means for all groups plotted within the 50th and 75th percentiles of WHO growth charts at Days 14, 30, and 60 and continued along the 75th percentile through Day 120 (Fig. 4a). For females, no significant differences in adjusted head circumference growth rates or achieved head circumference were detected. Mean achieved head circumferences for females in all groups plotted within the 50th and 75th percentiles of the WHO growth charts at all measured study time points (Fig. 4b).

\section{Tolerance}

fvNo group differences in parent-reported gassiness and fussiness were detected at any time point assessed, with the exception of fussiness at Day 30 (Table 4). Mean stool frequency was lower in the AAF versus the Control or EHF groups at Day $30(P<0.001)$; lower in EHF or AAF versus Control at Day $60(P \leq 0.025)$; and lower in AAF versus Control or EHF at Day $90 \quad(P \leq 0.008)$ (Table 5). No significant group differences were detected in mean stool frequency at Day 120. Significant differences in stool consistency were detected in the AAF versus Control or EHF groups at Days 30, 60, 90, and 120 $(P<0.001)$. At each measured time point, more infants with "unformed or seedy" and fewer infants with a "hard" or "formed" stool consistency in the Control and EHF groups compared to the AAF group were the primary differences observed in stool consistency categories.

With the exception of lower formula intake (fl oz.; mean \pm SE) at Day 60 for male infants in the Control $(30.2 \pm 1.0)$ versus the EHF $(33.4 \pm 1.1)$ or AAF $(34.2 \pm$ 1.1) groups $(P \leq 0.036)$, there were no significant group differences by sex detected at Days 30,60, 90, or 120 (Table 6). In addition, mean reported intakes increased from Day 30 to 120 for all groups indicating normal intake for this time period. No group difference was detected in the number of participants for whom at least one medically confirmed adverse event was reported (Control: 136, 79\%; EHF: 127, 75\%; AAF: 127, 80\%; $P=$ 0.476). The incidence of adverse events categorized within Body as a Whole; Cardiovascular; Eyes, Ears, Nose, and Throat; Musculoskeletal; Respiratory; or Urogenital systems had no statistically significant group differences for specific events. In the Gastrointestinal (GI) System, there were no significant group differences in the most commonly reported specific adverse event, gastroesophageal reflux (Control: 42, 24\%; EHF: 35, 21\%; AAF: 32, 20\%). The incidence of constipation was lower in the Control $(14,8 \%)$ or EHF $(10,6 \%)$ versus the AAF group (43, 27\%; $P<0.001$ ); the incidence of diarrhea was lower in the AAF $(2,1 \%)$ versus the Control $(13,8 \%)$ or EHF $(10,6 \% ; P \leq 0.036)$ groups. Within the Metabolic and Nutrition System, an overall significant difference was detected for poor weight gain (Control: 4, 2\%; EHF: 0; AAF: $0 ; P=0.036$ ) but no specific pairwise group differences were detected. Within the Skin System, the incidence of diaper rash was significantly higher in the Control $(26,15 \%)$ versus the $\operatorname{AAF}(9,6 \% ; P=0.007)$; no significant differences were detected compared to the 
Table 3 Weight, length, and head circumference growth rates from 14 days to $30,60,90$, and 120 days of age

\begin{tabular}{|c|c|c|c|c|}
\hline \multirow[b]{2}{*}{ Day } & \multirow[b]{2}{*}{ Group (n) } & \multirow[b]{2}{*}{$\begin{array}{l}\text { Weight } \\
\text { (g/day) }\end{array}$} & \multicolumn{2}{|l|}{ Growth rate $^{a}$} \\
\hline & & & $\begin{array}{l}\text { Length } \\
\text { (cm/day) }\end{array}$ & $\begin{array}{l}\text { Head circumference } \\
\text { (cm/day) }\end{array}$ \\
\hline \multicolumn{5}{|l|}{ male } \\
\hline \multirow[t]{3}{*}{30} & Control (90) & $35.3 \pm 1.3$ & $0.14 \pm 0.008$ & $0.076 \pm 0.004^{*} \dagger$ \\
\hline & EHF (80) & $37.8 \pm 1.4$ & $0.13 \pm 0.009$ & $0.091 \pm 0.004$ \\
\hline & AAF (82) & $39.7 \pm 1.4$ & $0.13 \pm 0.009$ & $0.098 \pm 0.004$ \\
\hline \multirow[t]{3}{*}{60} & Control (78) & $33.2 \pm 1.0$ & $0.12 \pm 0.004$ & $0.067 \pm 0.002 \dagger$ \\
\hline & EHF (67) & $34.7 \pm 1.1$ & $0.13 \pm 0.004$ & $0.071 \pm 0.002$ \\
\hline & $\operatorname{AAF}(67)$ & $36.4 \pm 1.1$ & $0.13 \pm 0.004$ & $0.076 \pm 0.002$ \\
\hline \multirow[t]{3}{*}{90} & Control (74) & $30.5 \pm 0.8$ & $0.11 \pm 0.002$ & $0.060 \pm 0.001 \dagger$ \\
\hline & EHF (60) & $31.7 \pm 0.9$ & $0.12 \pm 0.003$ & $0.060 \pm 0.002 \dagger$ \\
\hline & AAF (64) & $33.0 \pm 0.9$ & $0.12 \pm 0.003$ & $0.067 \pm 0.001$ \\
\hline \multirow[t]{3}{*}{120} & Control (71) & $28.6 \pm 0.7$ & $0.11 \pm 0.002$ & $0.054 \pm 0.001 \dagger$ \\
\hline & EHF (57) & $29.5 \pm 0.8$ & $0.11 \pm 0.002$ & $0.054 \pm 0.001 \dagger$ \\
\hline & AAF (63) & $30.5 \pm 0.7$ & $0.11 \pm 0.002$ & $0.059 \pm 0.001$ \\
\hline \multicolumn{5}{|l|}{ female } \\
\hline \multirow[t]{3}{*}{30} & Control (62) & $31.6 \pm 1.3$ & $0.12 \pm 0.009$ & $0.075 \pm 0.004$ \\
\hline & EHF (58) & $33.0 \pm 1.4$ & $0.14 \pm 0.009$ & $0.077 \pm 0.005$ \\
\hline & AAF (59) & $32.9 \pm 1.3$ & $0.13 \pm 0.009$ & $0.081 \pm 0.005$ \\
\hline \multirow[t]{3}{*}{60} & Control (55) & $28.3 \pm 1.0$ & $0.11 \pm 0.004$ & $0.063 \pm 0.002$ \\
\hline & EHF (52) & $28.1 \pm 1.0$ & $0.12 \pm 0.004$ & $0.063 \pm 0.002$ \\
\hline & $\operatorname{AAF}(50)$ & $29.8 \pm 1.0$ & $0.11 \pm 0.004$ & $0.069 \pm 0.002$ \\
\hline \multirow[t]{3}{*}{90} & Control (49) & $26.0 \pm 0.9$ & $0.11 \pm 0.003$ & $0.055 \pm 0.002$ \\
\hline & EHF (50) & $25.7 \pm 0.9$ & $0.11 \pm 0.003$ & $0.054 \pm 0.002$ \\
\hline & AAF (49) & $26.8 \pm 0.9$ & $0.11 \pm 0.003$ & $0.058 \pm 0.002$ \\
\hline \multirow[t]{3}{*}{120} & Control (45) & $24.8 \pm 0.8$ & $0.10 \pm 0.002$ & $0.050 \pm 0.001$ \\
\hline & EHF (49) & $24.2 \pm 0.8$ & $0.10 \pm 0.002$ & $0.049 \pm 0.001$ \\
\hline & AAF (46) & $25.1 \pm 0.8$ & $0.10 \pm 0.002$ & $0.050 \pm 0.001$ \\
\hline
\end{tabular}

${ }^{a}$ mean \pm standard error (SE); adjusted mean \pm SE for Head Circumference for females

*Significantly different vs EHF, $P<0.05$

†Significantly different vs AAF, $P<0.05$

EHF (16, 9\%) group. Any medically confirmed adverse event was considered serious if it met one or more of the following criteria: resulted in death, was lifethreatening, required inpatient hospitalization or prolongation of existing hospitalization, resulted in persistent or significant disability/incapacity, or was a congenital anomaly/birth defect. A total of 16 participants experienced serious adverse events (Control: 5, 3\%; EHF: 5, 3\%; AAF: 6, 4\%). All serious adverse events were individually evaluated by study site physicians and each was determined unrelated to study formula.

\section{Discussion}

This study demonstrated that two investigational hypoallergenic formulas, an EH casein formula with added
LGG (2.4 g protein $/ 100 \mathrm{kcal}$ ) and an AA-based formula $(2.4 \mathrm{~g}$ protein equivalent $/ 100 \mathrm{kcal})$, were safe and welltolerated when fed to healthy term infants from 14 to 120 days of age. Rate of weight gain (g/day), per guidance provided by the AAP Task Force on Clinical Testing of Infant Formulas [22], was used as the primary variable to assess the nutritional suitability of study formulas. No statistically significant group differences were observed for weight and length growth rates from 14 to 120 days of age. No group differences were detected in mean head circumference growth rates for females. Significant differences were observed for males: mean head circumference growth rate was higher for the AAF compared to Control at all time points and higher than the EHF group at Days 90 and 120. However, mean achieved weight, length, and head circumference plotted on WHO charts demonstrated normal growth throughout the study period. There were no group differences in achieved weight (males and females), length (males and females), and head circumference (females) and means were within the 25th and 75th percentiles of the WHO growth chart from 14 to 120 days of age. With the exception of Day 90, there were no statistically significant group differences in achieved head circumference for males; means remained between the 50th and 75th percentiles of growth by WHO standards at Days 14, 30, and 60 and continued along the 75th percentile through Day 120. In addition, all clinical outcomes related to head circumference growth were considered normal.

The randomized, double-blind, controlled design is a key strength of this study. One limitation could be that an AAbased formula at $2.8 \mathrm{~g}$ protein $/ 100 \mathrm{kcal}$ was not included as a study formula. However, we have previously reported that an AA-based formula (vs a control casein $\mathrm{EH}$ formula) and a casein EH formula with added LGG (versus a control casein EH formula with no added LGG) were safe and supported growth in healthy, term infants in studies of comparable design [14, 25]. The growth rates reported in these previous studies were similar to those demonstrated in the current study of reduced protein EHF and AAF formulations. In addition, no breastfed reference group was registered for comparison within this clinical trial.

It is well known that infants fed formula grow on a different trajectory than infants exclusively receiving breast milk $[10,11,26]$. Upper limit recommendations for total protein content for inclusion in infant formulas have been reduced in recent years with the premise of supporting infants receiving formula to grow more similarly to breastfed infants. In the current study, we have compared two reduced protein formulas to an existing in-market formula demonstrated to support adequate growth in infants, which is in accordance with AAP guidance [22]. We did not enroll an additional breastfed 

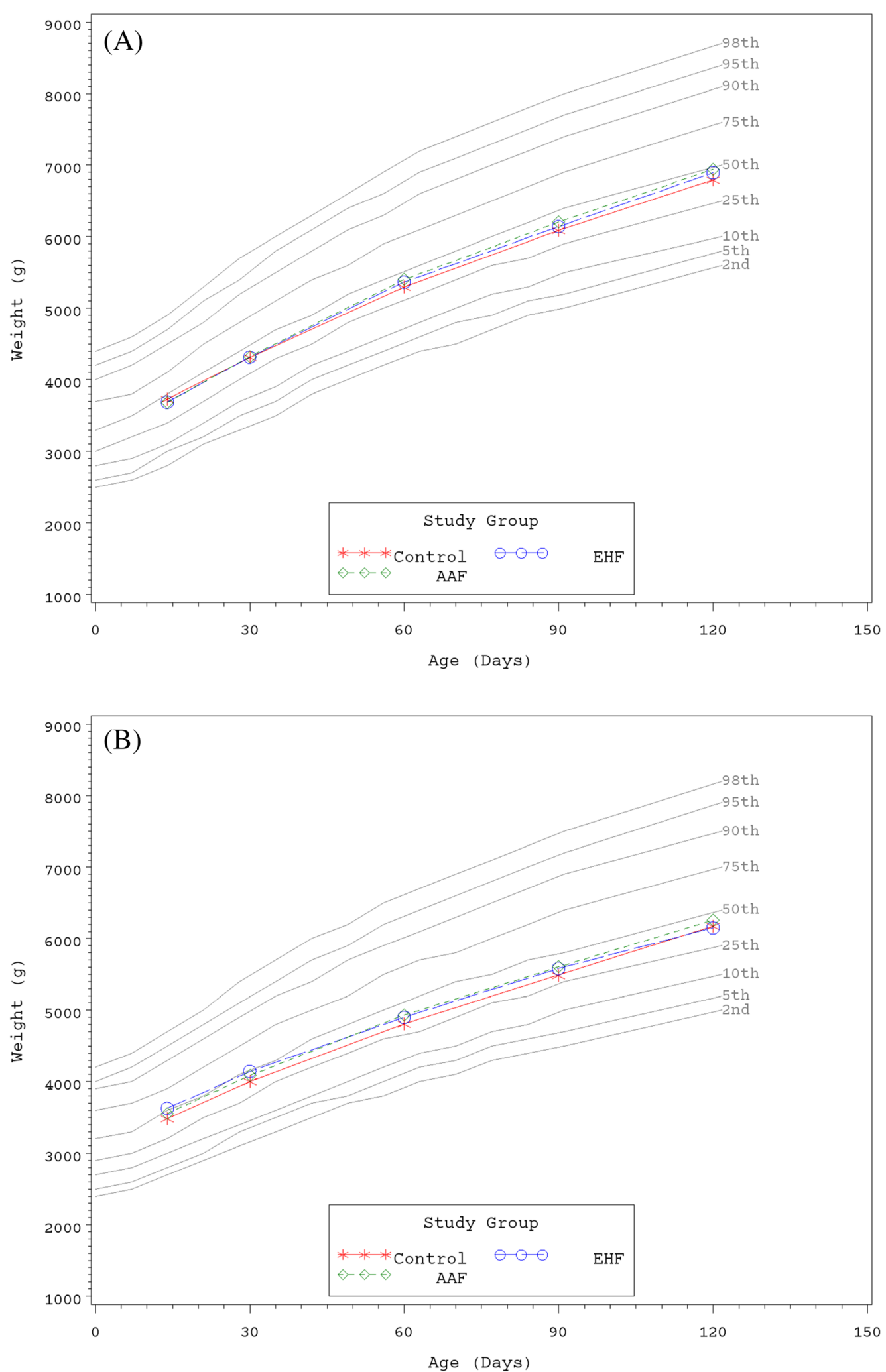

Fig. 2 a Mean achieved weight for male participants with World Health Organization (WHO) percentiles (2nd to 98th) from 14 to 120 days of age. Control, stars; EHF, circles; AAF, diamonds. b Mean achieved weight for female participants with World Health Organization (WHO) percentiles (2nd to 98th) from 14 to 120 days of age. Control, stars; EHF, circles; AAF, diamonds 

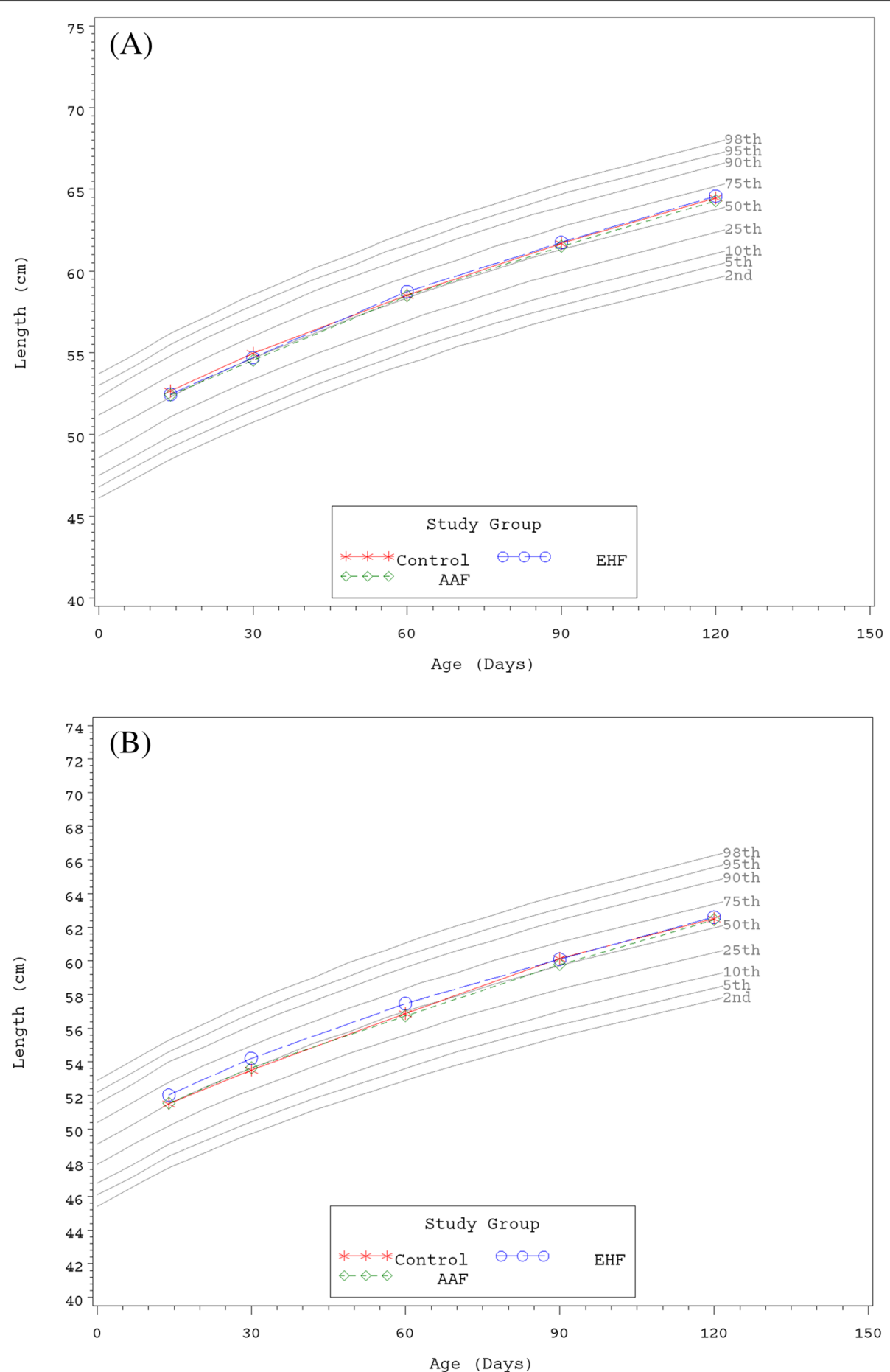

Fig. 3 a Mean achieved length for male participants with World Health Organization (WHO) percentiles (2nd to 98th) from 14 to 120 days of age. Control, stars; EHF, circles; AAF, diamonds. b Mean achieved length for female participants with World Health Organization (WHO) percentiles (2nd to 98th) from 14 to 120 days of age. Control, stars; EHF, circles; AAF, diamonds

reference group for comparison. However, growth data were plotted using the WHO reference standards, which are representative of typical growth of breastfed infants. As such, the growth data reported herein were effectively compared against a breastfed reference standard. 

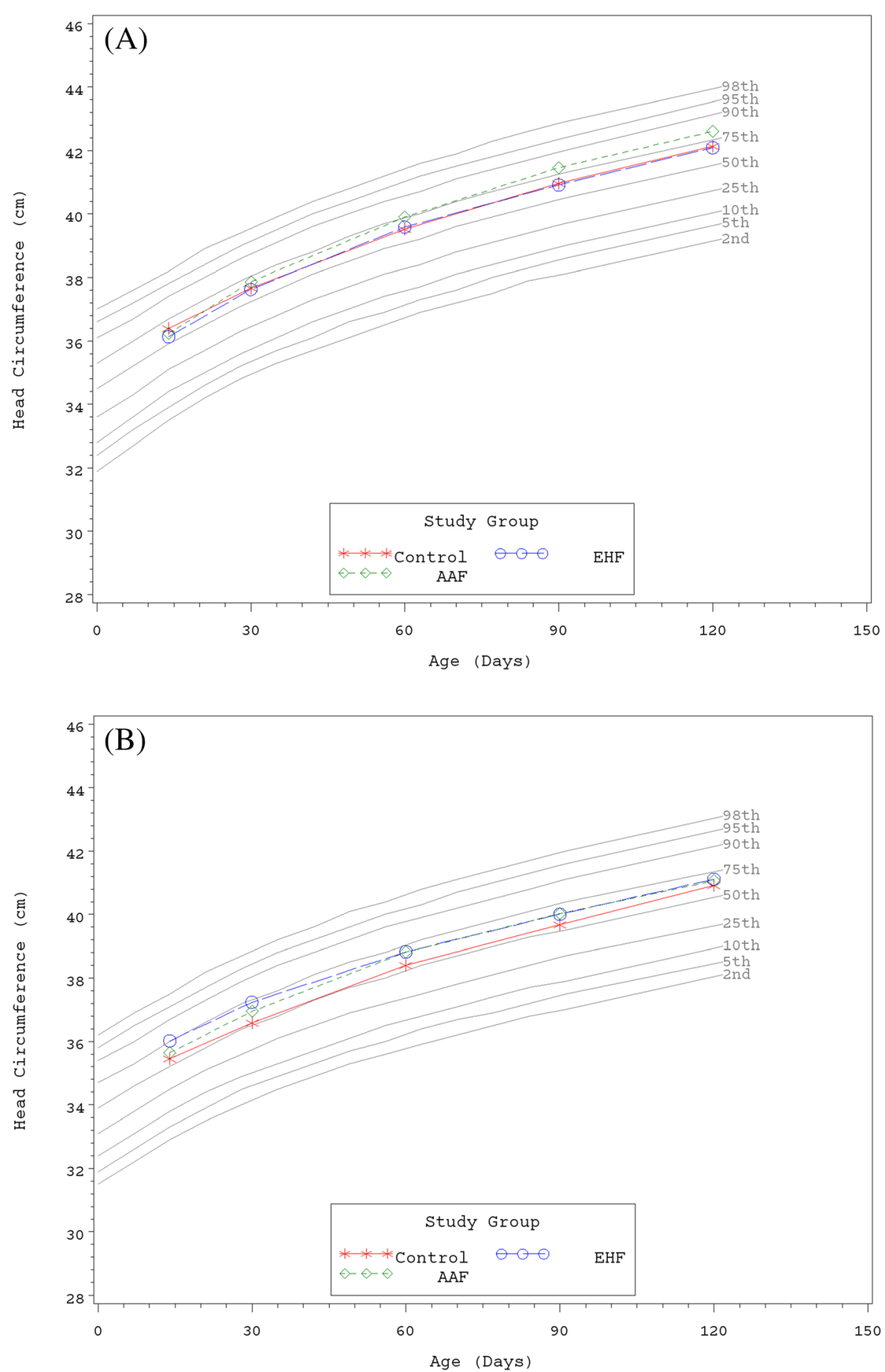

Fig. 4 a Mean achieved head circumference for male participants with World Health Organization (WHO) percentiles (2nd to 98th) from 14 to 120 days of age. Control, stars; EHF, circles; AAF, diamonds. b Mean achieved head circumference for female participants with World Health Organization (WHO) percentiles (2nd to 98th) from 14 to 120 days of age. Control, stars; EHF, circles; AAF, diamonds

Overall, acceptance and tolerance of study formulas were good. No differences in study discontinuation due to study formula were detected. Aside from fussiness at day 30, no significant group differences were detected in fussiness or gassiness. Mean stool frequency was not significantly different among groups by Day 120 but 
Table 4 Fussiness and gassiness at Days 14, 30, 60, 90, and 120

\begin{tabular}{|c|c|c|c|c|c|c|c|c|c|c|c|c|}
\hline \multirow[b]{2}{*}{ Day } & \multirow[b]{2}{*}{ Group } & \multicolumn{5}{|c|}{ Fussiness, n (\%) } & \multirow[b]{2}{*}{$P$} & \multicolumn{4}{|c|}{ Gassiness, n (\%) } & \multirow[b]{2}{*}{$P$} \\
\hline & & $\begin{array}{l}\text { Not at } \\
\text { all }\end{array}$ & Slightly & Moderately & Very & Extremely & & $\begin{array}{l}\text { None at } \\
\text { all }\end{array}$ & $\begin{array}{l}\text { Slight } \\
\text { amount }\end{array}$ & $\begin{array}{l}\text { Moderate } \\
\text { amount }\end{array}$ & $\begin{array}{l}\text { Excessive } \\
\text { amount }\end{array}$ & \\
\hline \multirow[t]{3}{*}{14} & Control & $43(25)$ & $90(52)$ & $34(20)$ & $4(2)$ & $2(1)$ & 0.513 & $11(6)$ & $75(43)$ & $73(42)$ & $14(8)$ & 0.791 \\
\hline & EHF & $52(31)$ & $85(50)$ & $26(15)$ & $6(4)$ & $1(1)$ & & $12(7)$ & $72(42)$ & $73(43)$ & $13(8)$ & \\
\hline & AAF & $40(25)$ & $81(51)$ & $34(22)$ & $1(1)$ & $2(1)$ & & $14(9)$ & $64(41)$ & $72(46)$ & $8(5)$ & \\
\hline \multirow[t]{3}{*}{30} & Control & $16(11)$ & $67(48)$ & $43(30)$ & $14(10)$ & $1(1)$ & $0.029 *+$ & $9(6)$ & $59(42)$ & $64(45)$ & $9(6)$ & 0.611 \\
\hline & EHF & $21(17)$ & $66(54)$ & $30(25)$ & $4(3)$ & $1(1)$ & & $4(3)$ & $56(46)$ & $51(41)$ & $12(10)$ & \\
\hline & AAF & $22(18)$ & $60(49)$ & $37(30)$ & $2(2)$ & $2(2)$ & & $9(7)$ & $54(44)$ & $51(41)$ & $9(7)$ & \\
\hline \multirow[t]{3}{*}{60} & Control & $30(24)$ & $57(45)$ & $32(25)$ & $5(4)$ & $2(2)$ & 0.171 & $11(9)$ & $49(39)$ & $51(40)$ & $15(12)$ & 0.294 \\
\hline & EHF & $36(32)$ & $52(46)$ & $21(19)$ & $3(3)$ & $1(1)$ & & $8(7)$ & $55(49)$ & 44 (39) & $6(5)$ & \\
\hline & AAF & $28(25)$ & $53(46)$ & $26(23)$ & $5(4)$ & $2(2)$ & & $7(6)$ & $56(49)$ & $46(40)$ & $5(4)$ & \\
\hline \multirow[t]{3}{*}{90} & Control & $46(38)$ & $55(45)$ & $19(16)$ & $0(0)$ & $1(1)$ & 0.874 & $19(16)$ & $60(50)$ & $37(31)$ & $5(4)$ & 0.850 \\
\hline & EHF & $45(43)$ & $40(38)$ & $15(14)$ & $3(3)$ & $2(2)$ & & $12(11)$ & $56(53)$ & $32(30)$ & $5(5)$ & \\
\hline & AAF & 39 (35) & $54(48)$ & $15(13)$ & $4(4)$ & $0(0)$ & & $18(16)$ & $55(49)$ & $29(26)$ & $10(9)$ & \\
\hline \multirow[t]{3}{*}{120} & Control & $51(44)$ & $41(35)$ & $17(15)$ & $6(5)$ & $1(1)$ & 0.192 & $25(22)$ & $52(45)$ & $35(30)$ & $4(3)$ & 0.783 \\
\hline & EHF & $49(47)$ & 41 (39) & $10(10)$ & $4(4)$ & $1(1)$ & & $21(20)$ & $57(54)$ & $24(23)$ & $3(3)$ & \\
\hline & AAF & 35 (33) & $46(43)$ & 20 (19) & $5(5)$ & $0(0)$ & & $25(24)$ & $47(44)$ & $32(30)$ & $2(2)$ & \\
\hline
\end{tabular}

* Control vs EHF significantly different, $P=0.015$

+ Control vs AAF significantly different, $P=0.043$

Table 5 Stool characteristics at Days 14, 30, 60, 90, and 120

\begin{tabular}{|c|c|c|c|c|c|c|c|c|c|}
\hline \multirow[b]{2}{*}{ Day } & \multirow[b]{2}{*}{ Group (n) } & \multirow{2}{*}{$\begin{array}{l}\text { Stool } \\
\text { frequency }^{b}\end{array}$} & \multirow{2}{*}{$\begin{array}{l}\text { Overall } \\
P\end{array}$} & \multicolumn{5}{|c|}{ Stool consistency, n (\%) } & \multirow{2}{*}{$\begin{array}{l}\text { Overall } \\
P\end{array}$} \\
\hline & & & & hard & formed & soft & Unformed or seedy & watery & \\
\hline \multirow[t]{3}{*}{14} & Control (173) & $2.9 \pm 0.2$ & 0.352 & $3(2)$ & $5(3)$ & $67(40)$ & $87(52)$ & $6(4)$ & 0.679 \\
\hline & EHF (170) & $3.3 \pm 0.2$ & & $2(1)$ & $8(5)$ & $74(45)$ & $76(46)$ & $6(4)$ & \\
\hline & AAF (156) & $3.2 \pm 0.2$ & & $2(1)$ & $4(3)$ & $69(45)$ & $75(49)$ & $4(3)$ & \\
\hline \multirow[t]{3}{*}{30} & Control (140) & $3.6 \pm 0.2$ & $<0.001^{*} \dagger$ & $3(2)$ & $5(4)$ & $74(53)$ & $53(38)$ & $5(4)$ & $<0.001^{*}+$ \\
\hline & EHF (121) & $3.4 \pm 0.2$ & & $1(1)$ & $5(4)$ & $67(54)$ & $46(37)$ & $4(3)$ & \\
\hline & AAF (123) & $2.5 \pm 0.2$ & & $21(18)$ & $43(36)$ & $48(40)$ & $7(6)$ & $0(0)$ & \\
\hline \multirow[t]{3}{*}{60} & Control (125) & $3.0 \pm 0.1$ & $<0.001^{*} \neq$ & $1(1)$ & $3(2)$ & $67(54)$ & $47(38)$ & $6(5)$ & $<0.001^{*}+$ \\
\hline & EHF (113) & $2.5 \pm 0.1$ & & $0(0)$ & $3(3)$ & $58(53)$ & $42(38)$ & $7(6)$ & \\
\hline & AAF (114) & $2.2 \pm 0.1$ & & $8(7)$ & $27(25)$ & $62(56)$ & $11(10)$ & $2(2)$ & \\
\hline \multirow[t]{3}{*}{90} & Control (121) & $2.5 \pm 0.1$ & $0.008^{*} \dagger$ & $0(0)$ & $3(3)$ & $66(58)$ & $33(29)$ & $12(11)$ & $<0.001^{*}+$ \\
\hline & EHF (104) & $2.5 \pm 0.2$ & & $0(0)$ & $6(6)$ & $55(54)$ & $38(37)$ & $3(3)$ & \\
\hline & AAF (112) & $1.9 \pm 0.1$ & & $4(4)$ & $19(17)$ & $74(67)$ & $12(11)$ & $1(1)$ & \\
\hline \multirow[t]{3}{*}{120} & Control (116) & $2.4 \pm 0.1$ & 0.356 & $2(2)$ & $6(5)$ & $64(57)$ & $34(30)$ & $7(6)$ & $<0.001^{*}+$ \\
\hline & EHF (105) & $2.3 \pm 0.1$ & & $1(1)$ & $6(6)$ & $65(63)$ & $30(29)$ & $2(2)$ & \\
\hline & AAF (105) & $2.1 \pm 0.1$ & & $5(5)$ & $24(23)$ & $65(63)$ & $10(10)$ & $0(0)$ & \\
\hline
\end{tabular}

${ }^{a}$ 24-hour recall at study visits

${ }^{\mathrm{b}}$ Mean \pm standard error (SE)

* Control vs AAF significantly different, $P<0.05$

† EHF vs AAF significantly different, $P<0.05$

₹ Control vs EHF significantly different, $P<0.05$ 
Table 6 Mean study formula intake (fluid oz./day) at Days 30, 60, 90, and 120

\begin{tabular}{|c|c|c|c|c|c|c|c|}
\hline Day & Group & males, $\mathrm{n}$ & Mean \pm SE & $\begin{array}{c}\text { Overall } \\
P\end{array}$ & females, $n$ & Mean \pm SE & $\begin{array}{c}\text { Overall } \\
P\end{array}$ \\
\hline \multirow[t]{3}{*}{30} & Control & 84 & $27.1 \pm 0.9$ & 0.390 & 57 & $26.1 \pm 0.7$ & 0.976 \\
\hline & EHF & 70 & $27.7 \pm 1.0$ & & 53 & $26.3 \pm 0.7$ & \\
\hline & AAF & 70 & $28.9 \pm 1.0$ & & 53 & $26.2 \pm 0.7$ & \\
\hline \multirow[t]{3}{*}{60} & Control & 76 & $30.2 \pm 1.0$ & $0.017^{*} \dagger$ & 50 & $29.5 \pm 1.0$ & 0.556 \\
\hline & EHF & 62 & $33.4 \pm 1.1$ & & 51 & $29.6 \pm 1.0$ & \\
\hline & AAF & 66 & $34.2 \pm 1.1$ & & 49 & $30.9 \pm 1.0$ & \\
\hline \multirow[t]{3}{*}{90} & Control & 73 & $34.1 \pm 1.0$ & 0.247 & 48 & $30.6 \pm 1.2$ & 0.324 \\
\hline & EHF & 56 & $33.1 \pm 1.2$ & & 49 & $32.2 \pm 1.2$ & \\
\hline & AAF & 63 & $35.8 \pm 1.1$ & & 49 & $33.2 \pm 1.2$ & \\
\hline \multirow[t]{3}{*}{120} & Control & 71 & $36.4 \pm 1.2$ & 0.921 & 45 & $33.3 \pm 1.2$ & 0.222 \\
\hline & EHF & 57 & $37.0 \pm 1.4$ & & 48 & $35.3 \pm 1.1$ & \\
\hline & AAF & 61 & $37.0 \pm 1.3$ & & 45 & $36.1 \pm 1.2$ & \\
\hline
\end{tabular}

* Control vs EHF significantly different, $P=0.036$

† Control vs AAF significantly different, $P=0.007$

differed at other time points, with EHF and Control groups generally reporting more frequent stooling. Similarly, more infants in the EHF and Control groups reported "unformed or seedy" stool consistency and fewer "hard" or "formed" stools compared to infants in the AAF group.

\section{Conclusions}

In summary, the results of the current study suggest that an EH casein formula and an AA-based formula, both with reduced protein content (2.4 g protein equivalent/ $100 \mathrm{kcal})$, were well tolerated and associated with normal growth in healthy, term infants from 14 to 120 days of age.

\section{Abbreviations}

AA: amino acid; AAP: American Academy of Pediatrics; CMA: cow's milk allergy; $\mathrm{EH}$ : extensively hydrolyzed

\section{Acknowledgements}

The authors thank study site staff for their cooperation. The participation of parents and infants in this study is greatly acknowledged. We also thank Suzanne Stolz for study management.

\section{Authors' contributions}

CBA, WHJ, HD, JL, RR and MY assessed study participants and collected study data. TC conceived of and designed the study. CLH participated in study design and performed statistical analyses. JLW participated in study design and prepared the initial draft of the manuscript. $\mathrm{RH}$ participated in manuscript development. All authors interpreted data, contributed to the intellectual content, reviewed and revised the manuscript, and approved the final version.

\section{Funding}

The study was funded by the study sponsor, Mead Johnson Nutrition.

\section{Availability of data and materials}

The authors and study sponsor encourage and support the responsible and ethical sharing of data from clinical trials. De-identified participant data from the final research dataset used in the published manuscript may only be shared under the terms of a Data Use Agreement. Requests may be directed to the corresponding author. This study adheres to CONSORT guidelines.

\section{Declarations}

Ethics approval and consent to participate

Parents or legally authorized representatives provided written informed consent prior to enrollment. The research protocol and informed consent forms observing the Declaration of Helsinki (including October 1996 amendment) were approved by: the University of Louisville Institutional Review Board (IRB; Louisville, KY); the University of Nebraska Medical Center IRB (Omaha, NE); Western IRB (Olympia, WA); and Schulman IRB (now known as Advarra, Columbia, MD). The study complied with good clinical practices.

\section{Consent for publication}

Not applicable.

\section{Competing interests}

CBA, WHJ, HD, JL, RR and MY have received support for study site coordination and data collection from Mead Johnson Nutrition. CLH and JLW work in the Department of Medical Affairs and RH works in Nutrition Science at Mead Johnson Nutrition. TC was previously employed by Mead Johnson Nutrition.

\section{Author details \\ ${ }^{1}$ Southeastern Pediatric Associates, 364 Honeysuckle Road, Dothan, AL 36305, USA. 'Birmingham Pediatric Associates, 806 St Vincent's Drive, Suite 615, Birmingham, AL 35205, USA. ${ }^{3}$ Children's Medical Association, $8430 \mathrm{~W}$ Broward Blvd, Plantation, FL 33324, USA. “Woburn Pediatric Associates Research Dept, 7 Alfred Street, Suite 220, Woburn, MA 01801, USA. ${ }^{5}$ Central Arkansas Pediatric Clinic, 2301 Springhill Road, Suite 200, Benton, AR 72019, USA. ${ }^{6}$ Owensboro Pediatrics, 2200 East Parrish Ave, Owensboro, KY 42303, USA. ${ }^{7}$ Medical Affairs and Scientific Affairs, Reckitt/Mead Johnson Nutrition Institute, Evansville, IN 47721, USA.}

Received: 11 August 2020 Accepted: 18 March 2021

Published online: 21 July 2021

\section{References}

1. Rona RJ, Keil T, Summers C, Gislason D, Zuidmeer L, Sodergren E, et al. The prevalence of food allergy: a meta-analysis. J Allergy Clin Immunol. 2007; 120(3):638-46. https://doi.org/10.1016/j.jaci.2007.05.026.

2. Boyce JA, Assa'ad A, Burks AW, Jones SM, Sampson HA, Wood RA, et al Guidelines for the diagnosis and management of food allergy in the United States: summary of the NIAID-sponsored expert panel report. J Am Acad Dermatol. 2011;64(1):175-92. https://doi.org/10.1016/j.jaad.201 0.11 .020 . 
3. Savage J, Johns CB. Food allergy: epidemiology and natural history. Immunol Allergy Clin N Am. 2015;35(1):45-59. https://doi.org/10.1016/j.iac.2014.09.004.

4. Dunlop JH, Keet CA. Epidemiology of food allergy. Immunol Allergy Clin N Am. 2018;38(1):13-25. https://doi.org/10.1016/j.iac.2017.09.002.

5. Flom JD, Sicherer SH. Epidemiology of cow's milk allergy. Nutrients. 2019;11(5).

6. Meyer R, Groetch M, Venter C. When should infants with cow's milk protein allergy use an amino acid formula? A practical guide. J Allergy Clin Immunol Pract. 2018;6(2):383-99. https://doi.org/10.1016/j.jaip.2017.09.003.

7. Lönnerdal B. Nutritional and physiologic significance of human milk proteins. Am J Clin Nutr. 2003;77(6):1537S-43S. https:/doi.org/10.1093/ajcn/77.6.1537S.

8. Lien EL. Infant formulas with increased concentrations of a-lactalbumin. Am J Clin Nutr. 2003;77(6):1555S-8S. https://doi.org/10.1093/ajcn/77.6.1555S.

9. Rudloff S, Kunz C. Protein and nonprotein nitrogen components in human milk, bovine milk, and infant formula: quantitative and qualitative aspects in infant nutrition. J Pediatr Gastroenterol Nutr. 1997;24(3):328-44. https://doi. org/10.1097/00005176-199703000-00017.

10. Koletzko B, von Kries R, Closa R, Escribano J, Scaglioni S, Giovannini M, et al. Lower protein in infant formula is associated with lower weight up to age 2 y: a randomized clinical trial. Am J Clin Nutr. 2009;89(6):1836-45. https://doi. org/10.3945/ajcn.2008.27091.

11. Kramer MS, Guo T, Platt RW, Vanilovich I, Sevkovskaya Z, Dzikovich I, et al. Feeding effects on growth during infancy. J Pediatr. 2004;145(5):600-5. https://doi.org/10.1016/j.jpeds.2004.06.069.

12. EFSA NDA Panel (EFSA Panel on Dietetic Products Nutrition and Allergies). Scientific Opinion on the essential composition of infant and follow-on formulae. EFSA J. 2014;12(7):3760. https://doi.org/10.2903/j.efsa.2014.3760

13. EU Commission E. Commission delegated regulation (EU) 2016/127 of 25 September 2015 supplementing regulation (EU) no 609/2013 of the European Parliament and of the council as regards the specific compositional and information requirements for infant formula and followon formula and as regards requirements on information relating to infant and young child feeding. OJ. 2016;59:1-29. http://data.europa.eu/eli/reg_ del/2016/127/oj

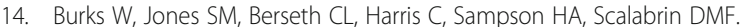
Hypoallergenicity and effects on growth and tolerance of a new amino acid-based formula with docosahexaenoic acid and arachidonic acid. J Pediatr. 2008;153(2):266-71. https://doi.org/10.1016/j.jpeds.2008.02.043.

15. US FDA: Title 21 Food and Drugs $\S 106$ Infant formula requirements pertaining to current Good Manufacturing Practice, Quality Control Procedures, Quality Factors, Recordsand Reports, and Notifications. US Congress https://ecfr.federa Iregister.gov/current/title-21/chapter-1/subchapter-B/part-106.

16. US FDA: Title 21 Food and Drugs $\$ 107$ Infant Formula: General provisions, labeling, exempt infant formulas, nutrient requirements, and infant formula recalls. US Congress https://ecfr.federalregister.gov/current/title-21/chapter-I/ subchapter-B/part-107.

17. Ashley C, JohnstonWH, Harris CL, Stolz SI, Wampler JL, Berseth CL. Growth and tolerance ofinfants fed formula supplemented with polydextrose (PDX) and/or galactooligosaccharides(GOS): double-blind, randomized, controlled trial. Nutr J. 2012:11:38. https://doi.org/10.1186/1475-2891-11-38

18. Yeiser M, Harris CL, Kirchoff AL, Patterson AC, Wampler JL, ZissmanEN, Berseth CL: Growth and tolerance of infants fed formula with a new algalsource of docosahexaenoic acid: Double-blind, randomized, controlled trial.Prostaglandins Leukot Essent Fatty Acids. 2016;115:89-96. https://doi. org/10.1016/j.plefa.2016.09.001.

19. Hoffman D, Ziegler E, Mitmesser SH, Harris CL, Diersen-Schade DA.Soybased infant formula supplemented with DHA and ARA supports growth andincreases circulating levels of these fatty acids in infants. Lipids. 2008; 43(1):29-35. https://doi.org/10.1007/s11745-007-3116-7.

20. Hoffman DR, HarrisCL, Wampler JL, Patterson AC, Berseth CL. Growth, tolerance, and DHA and ARAstatus of healthy term infants receiving formula with two different ARAconcentrations: Double-blind, randomized, controlled trial. ProstaglandinsLeukot Essent Fatty Acids. 2019;146:19-27. https://doi. org/10.1016/j.plefa.2019.04.007.

21. Johnston WH, Ashley C, Yeiser M, Harris CL, Stolz SI, Wampler JL, Wittke A, Cooper TR. Growth and tolerance of formula with lactoferrin ininfants through one year of age: double-blind, randomized, controlled trial.BMC Pediatr. 2015;15:173. https://doi.org/10.1186/s12887-015-0488-3.

22. AAP Task Force on Clinical Testing of Infant Formulas, Committee onNutrition (Finberg L, Bell EF, Cooke RJ, Fomon SJ, Kleinman RE, Pencharz PB,Reynolds JW, Schanler RJ, Forbes AL) Report: Clinical testing of infantformulas with respect to nutritional suitability for term infants. 1988.US
Foodand Drug Administration, Center for Food Safety and Applied Nutrition.1-16. https://wayback.archive-it.org/7993/20170722090324/https:// www.fda.gov/Food/GuidanceRegulation/GuidanceDocumentsRegula toryInformation/InfantFormula/ucm170649.htm.

23. WHO Multicentre Growth Reference Study Group, WHO Child Growth Standards based on length/height, weight and age. Acta Paediatr Suppl. 2006;450:76-85. https://doi.org/10.1111/j.1651-2227.2006.tb02378.x.

24. Department of Nutrition for Health and Development, World Health Organization; WHO child growth standards: Length/height-for-age,weightfor-age, weight-for-length, weight-for-height and body massindex-for-age-Methods and development. Geneva: World Health Organization;2006. https://apps.who.int/iris/handle/10665/43413.

25. Scalabrin DM, Johnston WH, Hoffman DR, P'Pool VL, Harris CL,Mitmesser SH: Growth and tolerance of healthy term infants receiving hydrolyzedinfant formulas supplemented with Lactobacillus rhamnosus GG. randomized, double-blind, controlled trial. Clin Pediatr(Phila). 2009;48(7):734-44. https:// doi.org/10.1177/0009922809332682

26. Kleinman RE, Greer FR(eds.). AAP Committee on Nutrition. Pediatric Nutrition, 8th edn: American Academy of Pediatrics; 2019.

\section{Publisher's Note}

Springer Nature remains neutral with regard to jurisdictional claims in published maps and institutional affiliations.
Ready to submit your research? Choose BMC and benefit from:

- fast, convenient online submission

- thorough peer review by experienced researchers in your field

- rapid publication on acceptance

- support for research data, including large and complex data types

- gold Open Access which fosters wider collaboration and increased citations

- maximum visibility for your research: over $100 \mathrm{M}$ website views per year

At BMC, research is always in progress.

Learn more biomedcentral.com/submissions 